\title{
Processing and Characterization of Natural Fiber Reinforced Polymer Composite
}

\author{
S. Kandwal, S. Singh, Bhupendra kumar
}

\begin{abstract}
Polymer materials synthetic fibers, for example, glass and carbon gives point of interest of high stiffness and strength to weight proportion when compare with conventional construction materials, for example wood, cement and steel. The accessibility of natural fibers and comfort of manufacturing have attempted researchers to try locally accessible inexpensive fibers and do study for their feasibility of strengthening purpose. Accordingly, many researchers do broad study on the properties of polymer matrix composite. The synthetic fiber substituting with the natural fiber for example, jute, sisal, pineapple and bamboo. The natural fiber removed by retting and manual procedures were exposed to soluble base treatment. this study is concerned with the investigation of mechanical properties of Grewia Optiva and jute fiber with epoxy resin matrix-based polymer composites. study investigate the tensile, bending and abrasion behavior of composites material made by grewia optiva and jute into epoxy resin. result shows that the better tensile strength of Grewia optiva fiber composite.
\end{abstract}

Key Words: Grewia optiva, jute, Epoxy, Tensile Strength.

\section{INTRODUCTION}

In present time plant fibers have been accepting impressive consideration as alternative for synthetic fiber reinforcements. Fiber reinforced materials have gained popularity. in high performance product that should be lightweight, yet sufficiently able to take brutal loading conditions. thin fibers can have exceptionally high strength, and form a well attached matrix so they can significantly improve the composite's general properties. fiber reinforced composite can be characterized in two ways. first one known as short fiber reinforced materials and second continuous fiber-reinforced materials. Continuous reinforced materials will regularly comprise a layered or overlaid structure. normally for compression and sheet moulding processes short and long fibers are used. Commonly for reinforcement high strength polymers are used for high temperature application. Natural fiber as reinforcement, attracted the consideration in view of other available materials. materials are ecologically friendly, completely decomposable, copiously accessible, renewable and low cost. Fibers extracted from the plants are very light weight as compared to other fibers.

Revised Manuscript Received on December 30, 2019.

* Correspondence Author

S. Kandwal, Assistant Professor, ME Department Institute of technology Gopeshwar Kothiyalsain, Chamoli, 246424 Uttarakhand, India

Dr. S. Singh, Designation: Associate Professor, ME Department BTKIT Dwarahat, Almora, 263653 Uttarakhand, India

Bhupendra kumar, Assistant Professor, ME Department Institute of technology Gopeshwar, Kothiyalsain, Chamoli, 246424 Uttarakhand, India

(c) The Authors. Published by Blue Eyes Intelligence Engineering and Sciences Publication (BEIESP). This is an open access article under the CC BY-NC-ND license (http://creativecommons.org/licenses/by-nc-nd/4.0/)
The ability of decomposition is the key point of plant fibers and they can give a well ecosystem. low cost and high performance of these composite accomplish the attention of industry economically.

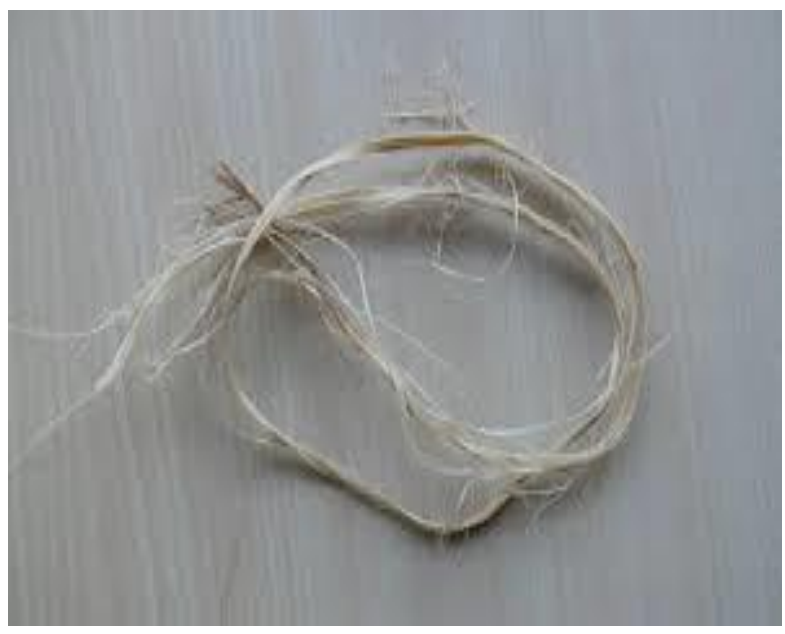

Figure 1: Grewia Optiva fiber

Natural fiber Grewia optiva possess good reinforcing ability when appropriately compounded with polymers. Natural fiber Grewia optiva is relatively inexpensive and easily accessible from renewable resources. Grewia optiva fiber-reinforced composites handled by compression molding.

\section{EXPERIMENT}

\section{A. Materials}

For the study bhimal (Grewia Optiva) and Jute (Corchorus oliotorus) fibers are used as composites specimen. The epoxy resin AW106 and hardener HV953IN synthetically having a place with the epoxide family which is utilized as the matrix material. and provided by ciba Geigy India Ltd. Epoxy resin have madules of $3.42 \mathrm{GPa}$ and possess density $1100 \mathrm{~kg} / \mathrm{m}^{3}$.

\section{B. Preparation of composite sample}

In this study prepare three different Composite which are shown in Table I.

Table II: Weight percent of specimen

\begin{tabular}{|r|l|c|c|c|}
\hline S.No. & $\begin{array}{c}\text { Name of the } \\
\text { sample }\end{array}$ & $\begin{array}{c}\text { Grewia } \\
\text { optiva (in \%) }\end{array}$ & $\begin{array}{c}\text { Jute (in } \\
\%)\end{array}$ & $\begin{array}{c}\text { Epoxy } \\
\text { Resin (in } \\
\% \text { ) }\end{array}$ \\
\hline 1. & Sample 1 & 50 & 30 & 20 \\
\hline 2. & Sample 2 & 60 & 20 & 20 \\
\hline 3. & Sample 3 & 40 & 40 & 20 \\
\hline
\end{tabular}


The materials prepared through hand layup process. In which raw bhimal (Grewia Optiva) and jute fibers of 300 mm are used for specimen.

Specimen consisting triple layers of bhimal (Grewia Optiva) fiber and two layers of jute fibers. In the presence of sunlight, the extracted fibers of bhimal (Grewia Optiva) and jute are dried. first place the layer of bhimal (Grewia Optiva) fiber, and fill the epoxy resin over the bhimal (Grewia Optiva) fiber after it fill the jute fiber over the resin. before the resin get dried again fill the subsequent layers. By using the rolling press, the air gaps formed during developing specimen are easily removed before it dried.

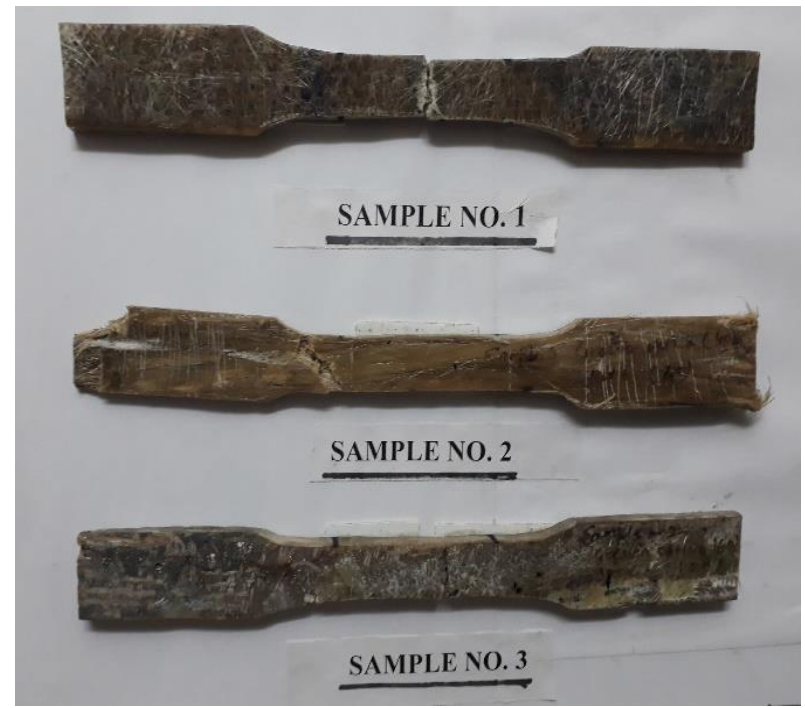

Figure 2: specimen of Grevia optiva and jute fiber reinforced composite

Finally, fiber composites are put under the press, for one day to get required shape and size. The size of specimen is 300x300x10 mm (Length, Width, Thickness). After dried, as per the required dimensions specimen neatly cut.

\section{Composite Material Testing:}

Tensile test: For the finding tensile properties in specimen the tensile test was done according to the ASTM (D 638) standard. The length of samples is $250 \mathrm{~mm}$, width $31 \mathrm{~mm}$ and thickness $7 \mathrm{~mm}$. in this study three types of specimens are prepared. The composition is shows in above Table 1. Universal Testing Machine (UTM) is used for test of specification. In UTM load is applying on specimen till specimen fractures. As a result, elongation formed and the value of elongation were noted and experiment repeated for other samples.

Flexural test: For the performing flexural test, all specimens are prepared according to the ASTM D790 standards. After the loading on specimen the deflection is measured. the value of flexural load and the displacements are recorded.

\section{RESULTS AND DISCUSSION}

In this study a composition of natural fiber Grewia optiva and jute are prepared. the tensile and flexural properties are finding and compared with the composite of gypsum and paper composite (sample 4). These results are given in Table II.
Table II. Tensile and flexural properties of specimen

\begin{tabular}{|l|c|c|c|}
\hline Sample & $\begin{array}{c}\text { Tensile } \\
\text { load (N) }\end{array}$ & $\begin{array}{c}\text { Flexural load } \\
\text { (N) }\end{array}$ & $\begin{array}{c}\text { Displacement } \\
(\mathbf{m m})\end{array}$ \\
\hline Sample 1 & 2900 & 688 & 0.80 \\
\hline Sample 2 & 3458 & 546.05 & 1.10 \\
\hline Sample 3 & 2640 & 1657.20 & 0.40 \\
\hline Sample 4 & 1600 & 889 & 0.70 \\
\hline
\end{tabular}

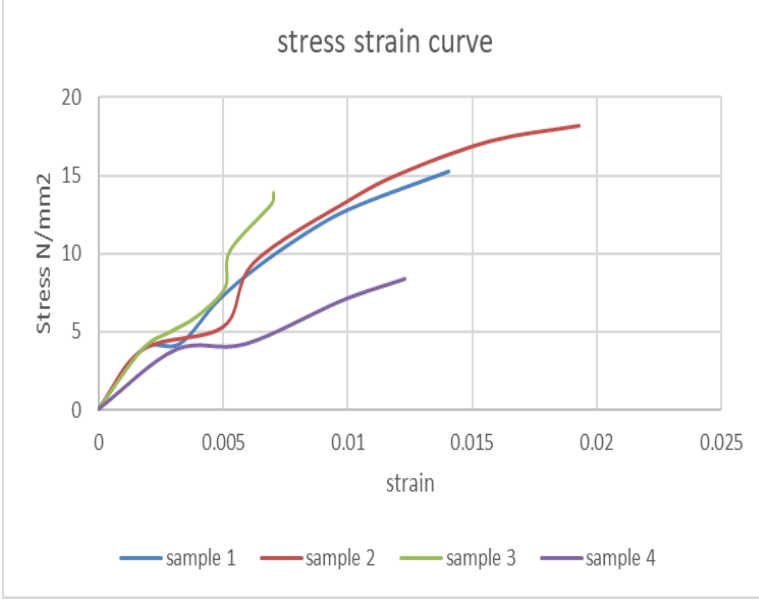

Figure 3: Stress strain curve for different sample

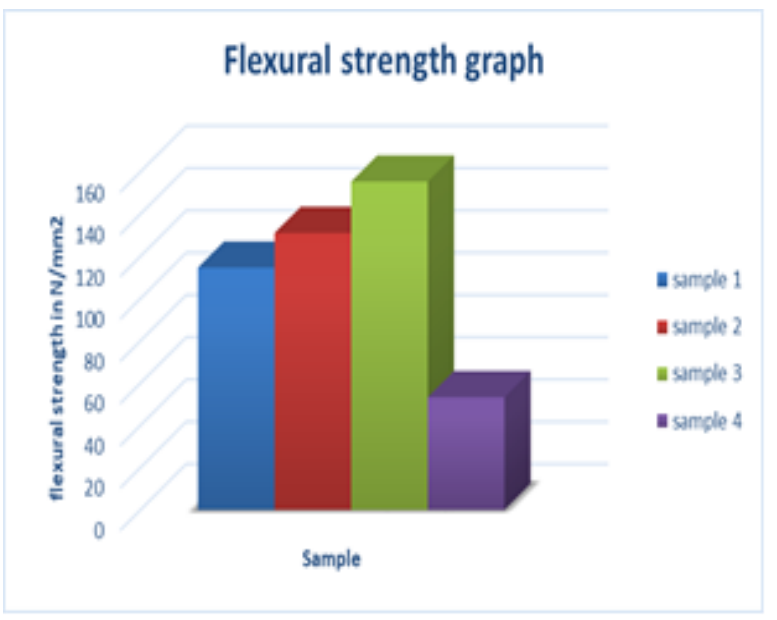

Figure 4: flexural strength graph for different sample

\section{CONCLUSION}

The bhimal (Grewia optiva) fiber with jute fiber composite specimens are prepared. From the experiment, it is concluded that the bhimal /jute fiber composite samples possess good tensile strength as compare to Gypsum/paper composite (sample 4) and can withstand the strength up to $18.2 \mathrm{~N} / \mathrm{mm}^{2}$. The bhimal (Grewia optiva) fiber with jute fiber composite specimen is holding the maximum flexural load of 1657.20 N higher than the Gypsum/paper composite (sample 4).

Published By: 


\section{REFERENCES}

1. alemdar and M.sain, composite science and technology 68(2008) 557

2. Elie Awwad, Mounir Mabsout, Bilal hamad and Helmi Khatib, Preliminary Studies on the use of natural fibers in sustainable concrete, Lebansese science journal,Vol. 12, No. 1,2011

3. U.S. Bongrade, V.D.Shinde, Review on natural fiber reinforcement polymer composites, international journal of Engineering Science and innovative technology (IJESIT) Volume 3, Issue 2, March 2014

4. D. Chandramohan, K.Marimuthu, A Review on natural Fibers, IJRRAS 8 (2), August 2011

5. M.R.Sanjay, G.R. Arpitha, L.Laxman Naik, K. Gopalakrishna, B.Yogesha., Application of natural

6. fibers and its composites, An Overview, 2016,7, 108-114.

7. M. Ramesh,K.Palanikumar, K.Hemchandra Reddy, Comparative Evaluation on Properties of Hybrid Glass Fiber- sisal/jute Reinforced Epoxy composites, Elsevier, 51 (2013) 745-750.

8. Vandana sharma, Bhanu M. Marwaha, Hemant K. Vinayak, enhancing durability of adobe by natural reinforcement for propagating sustainable mud housing, international journal of sustainable built environment (2016) 5,141-155.

9. Ajith Gopinath, Senthil kumar.M, Elayaperumal A, Experimental investigation on mechanical properties of jute fiber Reinforced composites with polyster and epoxy resin matrices, ScienceDirect, 97 (2014) 2052-2063.

10. A.S. Shingha, Vijay Kumar Thakur, Grewia Optiva Fiber Reinforced low cost Polymer composites, ISSN 0973-4945, 2009, 6(1), 71-76

11. WU Heng, FAN Shang-wu, YUAN Xiao-wen, CHEN Lai-Fei, DENG Juan -li, Fabrication of carbon fibers from jute fiber by pre oxidation and carbonization, Elsevier, Volume 28, Issue 6, Dec 2013.

\section{AUTHORS PROFILE}

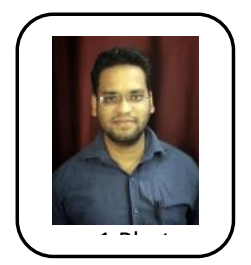

S. Kandwal, Designation: Assistant Professor, ME Dept.

Email Id: Sandeep.kandwal@itgopeshwar.ac.in

Education: M.Tech, PhD Pursuing.Publication: 02 in international journal

Member: ASME 2018,2019

Address:Institute of technology Gopeshwar Kothiyalsain, Chamoli, 246424 Uttarakhand,India

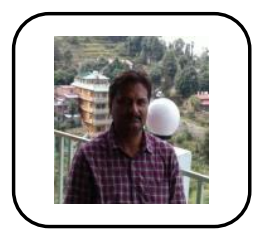

Dr. S. Singh, Designation: Associate Professor, ME Dept.Email Id: ssinghiitd@gmail.com

Education: PhD. IIT Delhi

Publication: more than 50 in international journals

Address:BTKIT Dwarahat, Almora, 263653

Uttarakhand,India

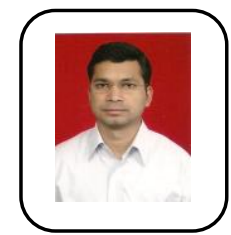

Bhupendra kumar,Designation: Assistant Professor, ME Dept.

Email Id: Bhupendra_94@yahoo.co.in

Education: M.Tech, PhD Pursuing.

Publication: 08 in international journals

Address:Institute of technology Gopeshwar,

Kothiyalsain, Chamoli, 246424

Uttarakhand, India 